\title{
The Cerebellum Harbors a Circadian Oscillator Involved in Food Anticipation
}

\author{
Jorge Mendoza, ${ }^{1}$ Paul Pévet, ${ }^{1}$ Marie-Paule Felder-Schmittbuhl, ${ }^{1}$ Yannick Bailly, ${ }^{2}$ and Etienne Challet $^{1}$ \\ ${ }^{1}$ Département de Neurobiologie des Rythmes and ${ }^{2}$ Département de Neurotransmission et Sécrétion Neuroendocrine, Centre National de la Recherche \\ Scientifique, Unité Propre de Recherche 3212 associée à l'Université de Strasbourg, Institut de Neurosciences Cellulaires et Intégratives, Institut Fédératif \\ des Neurosciences de Strasbourg, 67084 Strasbourg, France
}

The cerebellum participates in motor coordination as well as in numerous cerebral processes, including temporal discrimination. Animals can predict daily timing of food availability, as manifested by food-anticipatory activity under restricted feeding. By studying ex vivo clock gene expression by in situ hybridization and recording in vitro Per1-luciferase bioluminescence, we report that the cerebellum contains a circadian oscillator sensitive to feeding cues (i.e., whose clock gene oscillations are shifted in response to restricted feeding). Food-anticipatory activity was markedly reduced in mice injected intracerebroventricularly with an immunotoxin that depletes Purkinje cells (i.e., OX7-saporin). Mice bearing the hotfoot mutation (i.e., Grid2 ${ }^{\text {ho/ho }}$ ) have impaired cerebellar circuitry and mild ataxic phenotype. Grid $2^{\text {ho/ho }}$ mice fed ad libitum showed regular behavioral rhythms and day-night variations of clock gene expression in the hypothalamus and cerebellum. When challenged with restricted feeding, however, Grid ${ }^{\text {ho/ho }}$ mice did not show any food-anticipatory rhythms, nor timed feeding-induced changes in cerebellar clock gene expression. In hypothalamic arcuate and dorsomedial nuclei, however, shifts in Per1 expression in response to restricted feeding were similar in cerebellar mutant and wild-type mice. Furthermore, plasma corticosterone and metabolites before mealtime did not differ between cerebellar mutant and wild-type mice. Together, these data define a role for the cerebellum in the circadian timing network and indicate that the cerebellar oscillator is required for anticipation of mealtime.

\section{Introduction}

A circadian timing system made of a network of cerebral clocks and peripheral oscillators plays a crucial role in the anticipation of $24 \mathrm{~h}$ predictable environmental changes, such as the light-dark cycle and food availability. Central to the circadian system is a master clock, located in the suprachiasmatic nuclei that underlie entrainment to light (Ralph et al., 1990; Meijer and Schwartz, 2003; Hastings et al., 2007).

When feeding opportunity is limited to a short temporal window each day at the same time [restricted feeding (RF)], animals are able to anticipate the time of food access. Food-anticipatory rhythms include wheel-running activity, behavioral arousal or body temperature (Mistlberger, 1994; Mendoza, 2007). Sched-

\footnotetext{
Received Nov. 25, 2009; accepted Dec. 11, 2009.

Supported by ANR-07-JCIC-0111 (E.C., J.M.) and Centre National de la Recherche Scientifique (CNRS) (E.C., Y.B., P.P.). We thank J. Hubbard (Institut de Neurosciences Cellulaires et Intégratives, CNRS, Strasbourg, France) for English revision and Dr. F. Bolaños-Jiménez (Physiologie des Adaptations Nutritionnelles, Institut National de la Recherche Agronomique, Nantes, France) for helpful discussion. We are also indebted to Prof. J. Mariani and Dr. C. Levenes (UMR7102, CNRS, Université Pierre et Marie Curie, Paris, France) for their generous supply of hotfoot mice and to Dr. Stéphane Heitz for taking care of the breeding colony of this cerebellar mutant line. We thank Prof. M. Menaker (University of Virginia, Charlottesville, VA) for his generous gift of Per1:luc rats. The plasmids for synthesis of Per 1 and Per2 probes were generously donated by Dr. H. Okamura (Kyoto University, Japan), that for Rev-erb $\alpha$ by Dr. H. Dardente (Aberdeen University, UK) and that for Dbp probe by Dr. U. Albrecht (University of Fribourg, Switzerland). We also thank Dr. D. Sage for telemetry supervision, G. Bombarde for immunohistofluorescence and S. Dumont for metabolites and hormonal assays.

Correspondence should be addressed to Etienne Challet, Centre National de la Recherche Scientifique, UPR3212, INCI, 5 rue Blaise Pascal, 67084 Strasbourg, France. E-mail: challet@inci-cnrs.unistra.fr.

DOI:10.1523/JNEUROSCI.5855-09.2010

Copyright $\odot 2010$ the authors $\quad 0270-6474 / 10 / 301894-11 \$ 15.00 / 0$
}

uled restricted feeding is a dominant synchronizer for circadian oscillations in peripheral organs, such as the liver (Damiola et al., 2000; Hara et al., 2001; Stokkan et al., 2001). Numerous arguments, however, suggest that food anticipation does not result from conditional responses or interval measurements, but is the output of a circadian (i.e., self-sustained) clock (Mistlberger, 1994), most likely located in the brain (Davidson et al., 2003). The exact location of the food-entrainable clock remains uncertain, and it may actually reside in a network of coupled structures. Furthermore, food anticipation is expressed even if the suprachiasmatic nuclei are lesioned (Stephan et al., 1979; Marchant and Mistlberger, 1997). Despite extended investigation, targeted lesions in numerous brain structures within the forebrain and the brainstem led to the same negative conclusions (Mistlberger, 1994; Stephan, 2001). Food-anticipatory behaviors are reduced after only a few cerebral lesions, such as in the parabrachial nucleus (Davidson et al., 2000) and the core of the accumbens nucleus (Mendoza et al., 2005b). Orexinergic cues mediated by circulating ghrelin synthesized in the stomach enhance arousal related to food anticipation (Blum et al., 2009; LeSauter et al., 2009), while anorexigenic cues mediated by leptin may inhibit food anticipation (Mistlberger and Marchant, 1999).

The cerebellum is traditionally considered as a key structure for motor coordination (Ebner, 1998; Shadmehr and Krakauer, 2008). In addition, the cerebellar network participates in motor and spatial learning (Lalonde and Botez, 1990), as well as motivational processes (D’Agata et al., 1993; Caston et al., 1998). Furthermore, the cerebellum is engaged in tasks requiring temporal 
discrimination in the seconds-to-minutes range (Ivry et al., 2002; Mauk and Buonomano, 2004). The possible role of the cerebellum in the circadian scale has not been studied.

Interestingly, besides the well studied suprachiasmatic nuclei, the cerebellar cortex belongs to the cerebral regions in which clock gene rhythms have been detected (Akiyama et al., 1999; Namihira et al., 1999; Farnell et al., 2008), suggesting that the cerebellum could contain a circadian oscillator. Moreover, during meal anticipation, glucose utilization is specifically reduced in the cerebellar cortex (de Vasconcelos et al., 2006) while $c$-fos expression is increased in this structure (Poulin and Timofeeva, 2008). Therefore, the goal of this study was to explore the potential involvement of the cerebellum in food anticipation through a combination of behavioral, targeted lesion, mutant phenotyping and molecular approaches.

\section{Materials and Methods}

\section{Animals, housing, and diet}

Two-month-old male $\mathrm{C} 3 \mathrm{H}$ and C57BL/6J mice were purchased from Charles River Laboratories for the hypocaloric feeding and OX7-saporin experiment, respectively. Grid $2^{\text {ho/ }}$ mice on C57BL/6J background were bred and studied in our animal care facilities (Animal resource and experimentation platform, Chronobiotron, Neurosciences Federation of Strasbourg, IFR37, France). Two- to three-month-old, sex-matched mutant mice and wild-type littermates were used here. Per1:luciferase transgenic rats (Yamazaki et al., 2000) were bred in our animal care facilities kept in home cages in the same room conditions as those reported above for mice. All animals were housed in individual cages with running wheels, kept at $21 \pm 1{ }^{\circ} \mathrm{C}$ under a 12:12 h light-dark cycle (lights on at 07:00 A.M.) and had ad libitum access to tap water and food (standard chow pellets, 105; SAFE) for at least 2 weeks before the onset of experiment. Animals were weighed weekly during the whole experiment. Food intake during restriction was monitored by weighing food before and after food access.

All experiments were performed in accordance with the rules of the European Committee Council Directive of November 24, 1986 (86/609/ EEC) and the French Department of Agriculture (license number 67-88 to E.C.).

\section{Intracerebroventricular injections of OX7-saporin}

The immunotoxin OX7-saporin, which targets the antigen Thy-1.1, a cell-surface protein, selectively kills Purkinje cells when infused into the ventricles (Mattsson et al., 2004; Nolan and Freeman, 2006). Under gaseous anesthesia [2\% isoflurane in $\mathrm{O}_{2} / \mathrm{N}_{2} \mathrm{O}(50: 50)$ ], mice were set in a Kopf stereotaxic apparatus. A micropipette, connected to a $2 \mu \mathrm{l} \mathrm{Hamil-}$ ton syringe, was lowered into the lateral ventricle. The stereotaxic coordinates for the tip relative to bregma were $-0.1 \mathrm{~mm}$ anterior, $\pm 0.9 \mathrm{~mm}$ lateral, and $-3 \mathrm{~mm}$ ventral to the skull surface. Two microliters containing $0.12,0.25$ or $0.50 \mu \mathrm{g}$ of OX7-saporin (Advancing Targeting Systems) or vehicle (i.e., PBS) was then infused at a speed of $1 \mu \mathrm{l} / \mathrm{min}$. The $\mathrm{mi}-$ cropipette was left in place for additional $5 \mathrm{~min}$ before removal to allow for diffusion.

Immediately after surgery, mice were injected intramuscular with $0.03 \mathrm{ml} / 100 \mathrm{~g}$ of analgesic solution (buprenorphine hydrochloride, Sigma) to reduce postoperative pain. Mice were allowed $7 \mathrm{~d}$ to recover from surgery.

Telemetry recordings of wheel-running activity, locomotor activity, and body temperature

E-mitter (battery free) telemetry devices (MiniMitter Co.) measuring general motor activity (called here locomotor activity) and body temperature were implanted intraperitoneally under gaseous anesthesia $[2 \%$ isoflurane in $\mathrm{O}_{2} / \mathrm{N}_{2} \mathrm{O}$ (50:50)]. Wheel-running activity, locomotor activity and body temperature were recorded every $5 \mathrm{~min}$ (Vitalview acquisition system, MiniMitter).

\section{Protocols of timed feeding and brain sampling}

Experiment 1. To study the rhythmic expression of clock genes in the cerebellum, mice under a light-dark cycle (LD) were used under two different feeding conditions. A group had free access to food (food ad libitum, AL), while another group (hypocaloric feeding: HF) was submitted to a temporal calorie restriction paradigm, in which animals received the $66 \%$ of daily food intake at midday [Zeitgeber time (ZT)6] for at least 3 weeks as described previously (Mendoza et al., 2005a; Feillet et al., 2006). On the last day of food restriction, mice were killed with isoflurane overdose and decapitated in 8 groups of 4 mice, at $3 \mathrm{~h}$ intervals starting at ZT0. Mice sampled after ZT6 were fed at the usual time on that day.

Experiment 2. Young adult Per1:luciferase transgenic rats $(n=8)$ were kept under LD cycle and synchronized to restricted feeding schedules with $6 \mathrm{~h}$ to food access starting at midday (from ZT6 to ZT12). Rats under ad libitum food conditions were used as control $(n=8)$. After $20 \mathrm{~d}$ of restricted feeding conditions, animals were killed with intraperitoneal pentobarbital overdose $2 \mathrm{~h}$ before lights off (ZT10) and brains were rapidly removed for bioluminescence recording.

Experiment 3. One week after OX7-saporin lesions ( $n=6$ per group), wheel-running activity of mice was recorded under LD conditions with food ad libitum. Then, animals were exposed to temporal restricted feeding during $15 \mathrm{~d}$. The duration of daily food access lasted $8 \mathrm{~h}$ (from ZT4 to ZT12). Despite this relatively long access to food, 3 treated animals died for unknown reason (two having received a dose of $0.12 \mu \mathrm{g}$ of OX7saporin and another one of the $0.50 \mu \mathrm{g}$ dose group). After 2 weeks of food restriction, animals were not fed during daytime (i.e., fasting test). The same day, they had free access to food from lights offset (i.e., ZT12) and they were subsequently transferred to constant darkness conditions (DD). After 2 weeks under these conditions, animals were killed with isoflurane overdose and perfused for cerebellar histology.

Experiment 4. Cerebellar mutant (i.e., Grid ${ }^{\text {ho/t }}$ and Grid2 $2^{\text {ho/ho }}$ ) mice and wild-type littermates were kept under a LD cycle and subjected to restricted feeding schedules with a $6 \mathrm{~h}$ access to food from ZT6 to ZT12 (lights off) during $15 \mathrm{~d}$. After food restriction, animals were transferred to DD conditions and fed ad libitum.

Another set of Grid2 $2^{\text {ho/ho }}$ mice and wild-type littermates were kept under DD conditions with food ad libitum before exposing them for 3 weeks to a restricted feeding schedule of $6 \mathrm{~h}$ food access, starting at 12:00 A.M. (geographical time). After food restriction, animals were maintained in DD and fed ad libitum for 2 weeks.

For clock gene and biochemical analysis, Grid2 ${ }^{\text {ho/ho }}$ and wild-type mice under a LD cycle were either fed ad libitum or exposed to $6 \mathrm{~h}$ restricted feeding during 2 weeks, as above. Mice were killed with isoflurane overdose at ZT6 (i.e., just before mealtime for food-restricted mice) and $12 \mathrm{~h}$ later (ZT18).

\section{In situ hybridization}

Eighteen micrometer coronal sections of mouse brains were cut in a cryostat. Antisense RNA probes were transcribed in the presence of $\alpha^{35} \mathrm{~S}$ UTP $(1250 \mathrm{Ci} / \mathrm{mmol}$, PerkinElmer) according to the manufacturer's protocol (MAXIscript, Ambion). Here we used riboprobes for $r P e r 1$ (GenBank accession number AF156986), mPer2 (GenBank accession number NM016974) mRev-erb $\alpha$ (GenBank accession number NM145775) and $m D b p$ (GenBank accession number NM016974). Cerebellar sections were fixed in $4 \%$ phosphate-buffered paraformaldehyde, rinsed twice with PBS and then acetylated twice in $0.1 \mathrm{~m}$ triethanol-amine, washed again with PBS and dehydrated in a graded ethanol series. Sections were hybridized overnight with denatured antisense riboprobe $\left(1.10^{7} \mathrm{cpm} / \mathrm{ml}\right.$ of hybridization medium buffer) in a humid chamber at $54^{\circ} \mathrm{C}$ with radiolabeled probe in a solution containing $50 \%$ deionized formamide, $10 \%$ sulfate dextran, $1 \times$ Denhardt's solution, $2 \times$ SSC (sodium citrate saline), $0.5 \mathrm{mg} / \mathrm{ml}$ salmon sperm DNA, $0.25 \mathrm{mg} / \mathrm{ml}$ transfer RNA, and 10 $\mathrm{mm}$ dithiothreitol. Sections were then rinsed with SSC, treated with ribonuclease A (Sigma), rinsed with stringency washes of SSC and dehydrated in a graded ethanol series. Slices and radioactive standards were exposed for $5 \mathrm{~d}$ to an autoradiographic film (Biomax MS-1 Kodak, Sigma). Standards were included in each cassette to verify that the measured values of optical densities were in the linear response range of the film. Densitometric analysis of hybridization signals was performed using Image $(\mathrm{NIH})$. The optical density of specific signal was calculated by subtracting the intensity of staining background area measured in the molecular layer of the cerebellum area where no hybridization signal was 
detected, from that measured in the Purkinje/granular layers. Measures were made in the cerebellar vermis on three slices and averaged for a given brain. Measures in the hypothalamus were performed as previously described (Feillet et al., 2008). Data were expressed as relative optical density values.

\section{Recording of bioluminescence}

Perl activity was assessed by measuring bioluminescence from cerebral tissues (cerebellum and suprachiasmatic region) harvested from Per1: luciferase transgenic rats, following a method previously described (Yamazaki and Takahashi, 2005). Rats were killed $2 \mathrm{~h}$ before lights off and brains were rapidly removed and placed in cold Hanks basic salt solution (HBSS, H1641,Sigma) containing $0.035 \%$ of sodium bicarbonate (S8761, Sigma), HEPES (10 mm, H0887, Sigma) and antibiotics (100 $\mu \mathrm{g} / \mathrm{ml}$ penicillin and $100 \mathrm{U} / \mathrm{ml}$ streptomycin, P433, Sigma). Coronal sections (500 $\mu \mathrm{m}$ thick) of both suprachiasmatic region and cerebellum were made using a stainless steel rat brain matrix (Cat. No. SA-2120, Harvard Apparatus). We used a pair of scalpels to cut the brain regions into small sections (1.5- to 2.0-mm-thick squares). Then tissues were cultured on Millicell culture membranes (PICMORG 50, Millipore) in a $35 \mathrm{~mm}$ culture dish with $1.0 \mathrm{ml}$ of DMEM (DMEM, D2902, Sigma) supplemented with $0.35 \% \mathrm{D}(+)$ glucose (G7021, Sigma), sodium bicarbonate $(0.035 \%), 10$ mM HEPES, B27 (2\% Invitrogen 17504-044), antibiotics $(25 \mu \mathrm{g} / \mathrm{ml}$ penicillin and $25 \mathrm{U} / \mathrm{ml}$ streptomycin), and $0.1 \mathrm{~mm}$ beetle luciferin (Promega, E1602). Culture dishes were sealed with vacuum grease (silicon grease, Bardahl) and set in a Lumicycle device (Actimetrics) kept in a $37^{\circ} \mathrm{C}$ incubator for recording. Lumicycle Analysis software (Actimetrics) was used to calculate the peak time (acrophase) of Per1:luciferase rhythms from the raw data.

\section{Immunohistochemistry}

In experiment 1 , to study the rhythmic expression of PER2 in the cerebellum, mice under LD cycle were fed with food ad libitum or hypocaloric feeding for 2 weeks and killed with isoflurane overdose and perfused at 6 different $4 \mathrm{~h}$ intervals from the $24 \mathrm{~h}$ cycle $(n=4$ per group and time point). Brains perfused with $50 \mathrm{ml}$ of $0.9 \%$ saline followed by $50 \mathrm{ml}$ of cold $4 \%$ paraformaldehyde (PAF) in $0.1-\mathrm{M}$ phosphate buffer ( $\mathrm{PB} ; \mathrm{pH}$ 7.4) were removed, postfixed (overnight in $4 \% \mathrm{PAF}$ at $4^{\circ} \mathrm{C}$ ) and transferred to a cryoprotectant solution (buffered $30 \%$ sucrose) for $72 \mathrm{~h}$ at $4^{\circ} \mathrm{C}$. Brains were then frozen in isopentane at $-60^{\circ} \mathrm{C}$ and then stored at $-80^{\circ} \mathrm{C}$. Thirty $\mu \mathrm{m}$ coronal cryostat sections were cut through the cerebellum. Free-floating sections were washed in cold $50 \mathrm{~mm}$ Tris-buffered saline (TBS; pH 7.4; Sigma) and incubated in a solution of $3 \%$ of $\mathrm{H}_{2} \mathrm{O}_{2}$ (Sigma-Aldrich) in TBS for $30 \mathrm{~min}$ at room temperature. Sections were then rinsed in TBS, and incubated for $2 \mathrm{~h}$ in a blocking solution containing $10 \%$ normal donkey serum in TBS with $0.1 \%$ Triton X-100 $(0.1 \%$ TBS-X), followed by an incubation in the primary antibody (in $0.1 \%$ TBS-X plus $10 \%$ normal donkey serum) for $24 \mathrm{~h}$ at $4^{\circ} \mathrm{C}$. We used a rabbit polyclonal anti-PER2 (1:1000, affinity purified, raised against an epitope mapping the $\mathrm{C}$ terminus of mouse PER2, Alpha Diagnostic International). Sections were then rinsed in TBS-X and incubated for $2 \mathrm{~h}$ at $4^{\circ} \mathrm{C}$ with a biotinylated anti-rabbit IgG made in donkey (Jackson ImmunoResearch), diluted 1:2000 with $0.4 \%$ TBS-X. Thereafter, sections were rinsed in TBS-X and incubated for $1 \mathrm{~h}$ at room temperature with an avidin-biotin-peroxidase complex (Vectastain Standard Elite ABC Kit; Vector Laboratories). Next, sections were rinsed twice in TBS for $10 \mathrm{~min}$, and incubated with $0.025 \%$ 3,3'-diaminobenzidine (Sigma) with $0.01 \%$ $\mathrm{H}_{2} \mathrm{O}_{2}$ in $50 \mathrm{~mm}$ Tris buffer. Thereafter, sections were rinsed with TBS, wet-mounted onto gel-coated slides, dehydrated through a series of alcohols, soaked in xylene, and coverslipped with EUKITT. The number of immunoreactive cells was determined using NIH ImageJ software.

To assess Purkinje cells loss after OX7-saporin treatment (experiment 3 ), brains were processed as above, except that the primary antibody was a rabbit polyclonal anti-calbindin D-28K (1:20,000, Sigma).

To visualize expression of calbindin D-28K and PER2 in the Purkinje cells of Grid $2^{\text {ho/ho }}$ and wild-type mice (experiment 4), mice fed ad libitum were deeply anesthetized with a mixture of $5 \%$ ketamine and $5 \%$ xylazine ( $0.1 \mathrm{ml}$ of the mix per $30 \mathrm{~g}$, i.p.) and transcardially perfused in the morning with $4 \%$ PAF in $0.1 \mathrm{M} \mathrm{PB}$. Brains were then immersed overnight in the same fixative at $4^{\circ} \mathrm{C}$ and then dehydrated in graded ethanol before immersion in iso-butanol for $4 \mathrm{~d}$ and embedding in paraffin. Paraffin sections ( $8 \mu \mathrm{m}$ thick) were cut with a microtome (Leica). After deparaffinization in toluene and rehydration in decreasing concentrations of ethanol, the sections were rinsed in PB saline (PBS) and preincubated in a blocking solution of PBS containing 3\% normal goat serum (NGS) and $0.5 \%$ Triton X-100 for $1 \mathrm{~h}$. The sections were then incubated for at least $24 \mathrm{~h}$ in the dark with a mixture of rabbit polyclonal antibodies raised against PER2 (IgG Alpha Diagnostic International) and mouse monoclonal antibodies raised against anti-calbindin D-28K (Sigma) diluted, respectively, at $1 / 1000$ and $1 / 300$ in PBS containing $0.5 \%$ Triton and $0.3 \%$ NGS. The sections were rinsed in PBS containing $0.05 \%$ Triton and incubated for $3 \mathrm{~h}$ with Alexa 488 goat anti-rabbit (Invitrogen) and Alexa 546 goat anti-mouse (Invitrogen) antibodies respectively diluted 1/2000 and $1 / 1500$ in PBS containing $0.3 \%$ Triton. The sections were finally rinsed in PBS and mounted in Mowiol before examination with a fluorescence microscope (Axioskop-II Zeiss). Control procedures included omission of the primary or secondary antibodies and, incubation with supernatant resulting from the centrifugation of anti-PER2 antibodies (diluted 1/1000) preincubated with specific antigenic mouse PER2 peptide (Alpha Diagnostic International, diluted 1/500 - 1/50).

\section{Blood sampling for serum determinations}

Grid2 ${ }^{\text {ho/ho }}$ and wild-type mice exposed to LD cycle and restricted feeding schedules were killed at two different time points ZT6 (just before mealtime) and ZT18 (6 h after lights off). Brains were removed for in situ hybridization (see above) and trunk blood (1-1.5 ml) was collected in 2 $\mathrm{ml}$ Eppendorf tubes containing $10 \mu \mathrm{l}$ of $4 \%$ EDTA. Blood was centrifuged at $5000 \mathrm{rpm}$ for $10 \mathrm{~min}$ to obtain blood serum. Serum aliquots of $100 \mu \mathrm{l}$ were frozen at $-80^{\circ} \mathrm{C}$ for subsequent determination by colorimetric methods of plasma concentrations of glucose (method of Trinder, Glucose GOD-PAP Kit BIOLABO, REF: LP80009), free fatty acids (method ACS-ACOD; Kit NEFA-HR2 Wako) and triacylglycerides (commercial diagnostic kit Cat. no. TR0100, Sigma). Corticosterone concentrations were determined by enzyme immunoassay (EIA; Immunodiagnostic Systems).

\section{Analysis of activity and temperature data}

Daily rhythms of wheel-running activity, locomotor activity and body temperature under a light-dark cycle were analyzed with ClockLab software (Actimetrics). Activity profiles were plotted using SigmaPlot software. Food-anticipatory activity (FAA) and thermogenesis (FAT) were defined as increase in wheel-running, general activity and temperature rise occurring during the 3, 2 and 1 h before mealtime.

\section{Statistical analyses}

Data are presented as means \pm SEM. Unpaired Student's $t$ test was used to compare two groups. One-way and two-way analyses of variance (ANOVA) for repeated and independent measures followed by post hoc comparisons with the LSD Fisher test were used to compare more than two groups. All analyses were performed using Statistica software (Statistica 8.0, StatSoft).

\section{Results}

\section{Expression of clock genes and proteins in the cerebellum}

To assess the putative sensitivity of the cerebellum to feeding cues, we first challenged mice with daytime hypocaloric feeding. This paradigm involves a restricted feeding schedule that induces strong food-anticipatory activity, alterations in the suprachiasmatic clockwork and body mass loss (Mendoza et al., 2005a; Feillet et al., 2006). Expression of clock genes and proteins in the cerebellum was studied by using in situ hybridization and immunohistochemistry, respectively. In mice fed ad libitum (i.e., with free access to food), rhythmic expression of Per1 and Per2 genes in the cerebellum was maximal in early night (ZT15, i.e., $3 \mathrm{~h}$ after lights off, $p<0.01$; Fig. $1 A, B$ ), while expression of PER2 protein peaked at ZT20 $(p<0.01$; supplemental Fig. S1, available at www.jneurosci.org as supplemental material). 
A

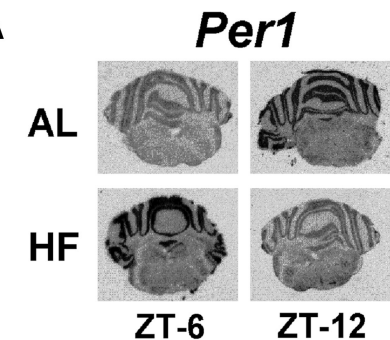

B

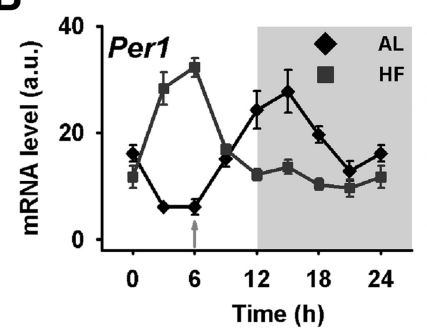

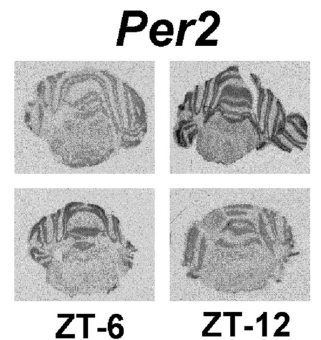



Rev-erb $\alpha$

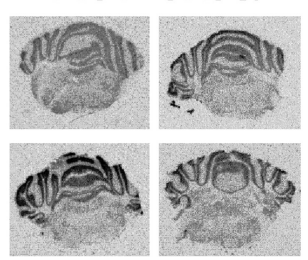

ZT-6

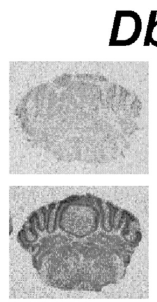

ZT-6
Dbp

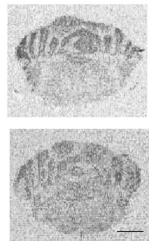

ZT-12

Figure 1. A, Expression of the clock genes Per1,Per2, Rev-erb $\alpha$, and Dbp in the cerebellum of wild-type mice under AL and hypocaloric feeding (HF) conditions. Scale bar, $50 \mu$ m. $\boldsymbol{B}$, Daily profiles of Per1, Per2, Rev-erb $\alpha$, and Dbp mRNA levels in the cerebellum of mice under AL and HF conditions (mean \pm SEM, $n=4$; per group and time point). Time of feeding is indicated by a vertical arrow $6 \mathrm{~h}$ after lights on (ZT12 = lights off). Data for ZT0 are double plotted at ZT24.
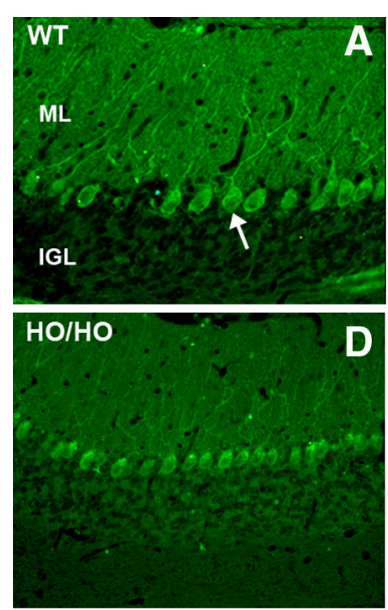
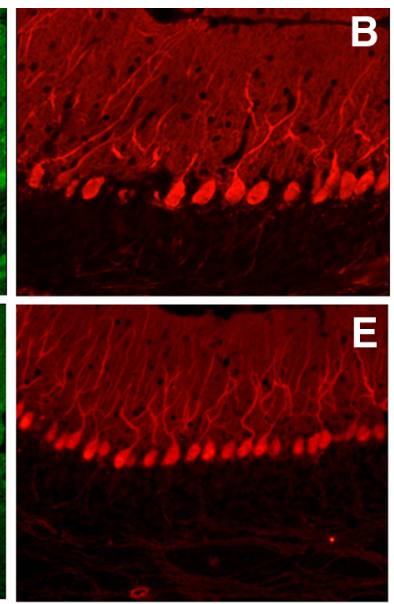
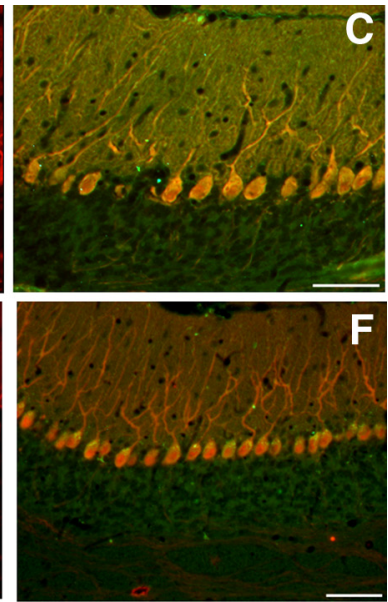

Figure 2. Double PER2 and calbindin D-28K immunofluorescent labeling of Purkinje cells in the cerebellar cortex of wild-type and cerebellar mutant (Grid2 ${ }^{\text {ho/ho }}$ ) mice. The somatodendritic compartment of the wild-type (WT) and Grid2 ${ }^{\text {ho/ho }}$ (HO/HO) Purkinje cells (arrow) display green PER2 $(\boldsymbol{A}, \boldsymbol{D})$ and red calbindin $(\boldsymbol{B}, \boldsymbol{E})$ immunofluorescence. $\boldsymbol{C}$, Merge of $\boldsymbol{A}$ and $\boldsymbol{B} ; \boldsymbol{F}$, merge of $\boldsymbol{D}$ and $\boldsymbol{E}$. IGL, internal granular layer; $\mathrm{ML}$, molecular layer. Scale bars, $50 \mu \mathrm{m}$.

Interestingly, PER2 expression in the cerebellum was restricted to the Purkinje cells (Fig. 2A-C; supplemental Fig. S1, available at www.jneurosci.org as supplemental material). Control procedures for PER2 immunohistofluorescence are shown in supplemental Fig. S2, available at www.jneurosci.org as supplemental material. Rev$e r b \alpha$ and $D b p$ genes were also expressed in a diurnal manner $(p<$ 0.01 ) with a peak in late daytime (ZT9) and early night (ZT14), respectively (Fig. $1 A, B$ ). In response to daytime hypocaloric feeding, Per1 and Per2 expression was phase-advanced by $9 \mathrm{~h}$ $(p<0.01$; Fig. $1 A, B)$. Expression of PER2 in hypocalorie-fed mice, albeit dampened, was also markedly phase-advanced (supplemental Fig. S1, available at www.jneurosci.org as supplemental material). Furthermore, the timing of Rev-erb $\alpha$ and $D b p$ expression in the cerebellum was advanced by 3 and $6 \mathrm{~h}$, respectively, compared with ad libitum food conditions $(p<0.01$; Fig. $1 A, B)$. This first set of data clearly indicates that the cerebellum expresses clock components whose expression can be modified by timed feeding conditions.

Bioluminescence of Per1:luciferase in the cerebellar cortex

To determine whether the cerebellar cortex is capable of generating intrinsic circadian rhythmicity, we then monitored Per1:luciferase bioluminescence in cerebellar and suprachiasmatic slices from rats fed ad libitum. Both regions displayed sustained circadian rhythms of Per1:luciferase expression $(8 / 9$ and $5 / 9$ in the suprachiasmatic region and cerebellar cortex, respectively), albeit those in the cerebellum were of lower amplitude, consistent with earlier observations in other extra-suprachiasmatic brain regions (Abe et al., 2002). In that study, Per1:luciferase expression was found not to be clearly rhythmic in a small set of cerebellar samples. Here Perl:luciferase expression reached its maximum in the suprachiasmatic nuclei at projected ZT8.1 $\pm 0.4 \mathrm{~h}$ (i.e., late subjective day; Fig. $3 A, G$ ) as previously described (Abe et al., 2002) and in the cerebellar cortex at projected ZT14.0 \pm 1.1 h (i.e., early night; Fig. $3 B, G$ ).

To determine whether the cerebellar circadian rhythmicity was sensitive to the synchronizing effects of timed feeding conditions, we exposed Per1:luciferase rats to temporally restricted feeding diet. The rats showed regular food-anticipatory activity (data not shown). We sampled their suprachiasmatic nuclei and cerebellum for monitoring in vitro Per1:luciferase bioluminescence. From 8 cultures, rhythmicity persisted in vitro in 8 suprachiasmatic and 5 cerebellar samples. While phase of circadian oscillations in the suprachiasmatic slices was unaffected by temporally restricted feeding (AL, peak at ZT8.1 $\pm 0.4 \mathrm{~h}$ vs RF, ZT7.6 $\pm 0.7 \mathrm{~h}, p=0.4$; Fig. $3 C, E, G)$, the circadian timing in the cerebellum was advanced in response to daytime restricted feeding, highlighting the sensitivity of the cerebellar clockwork to feeding and metabolic cues (AL, peak at ZT14.0 $\pm 1.1 \mathrm{~h}$ vs RF, ZT6.9 $\pm 0.7 \mathrm{~h}, p<0.001$; Fig. $3 D, F, G)$. The endogenous period 

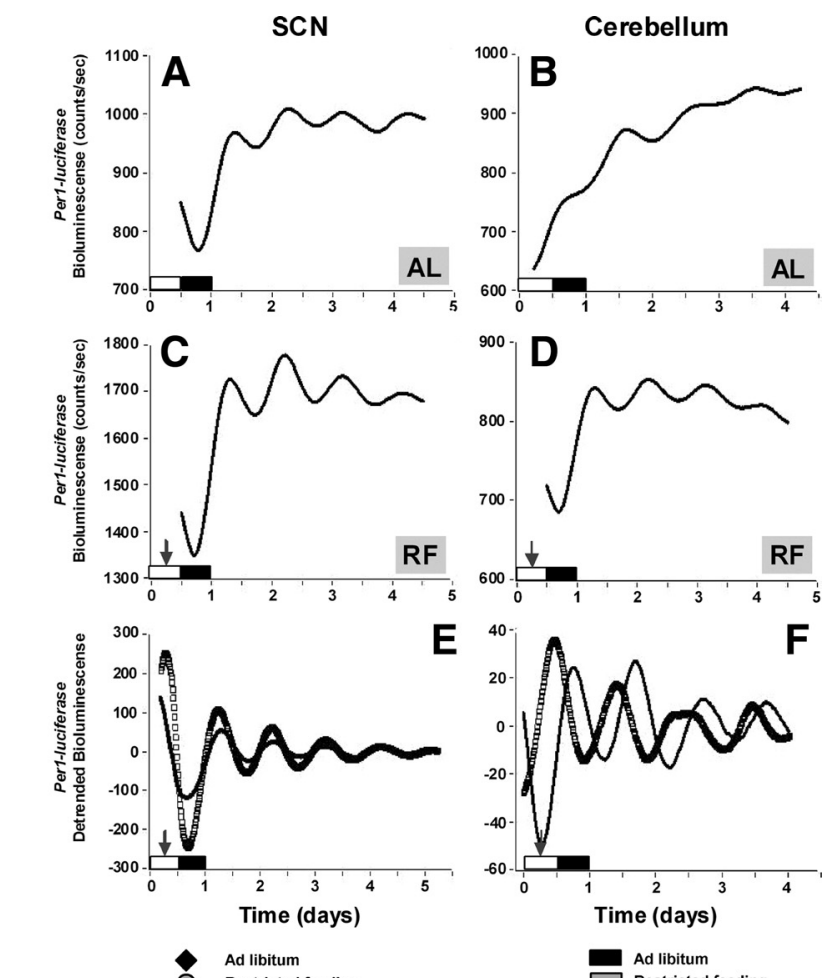

E
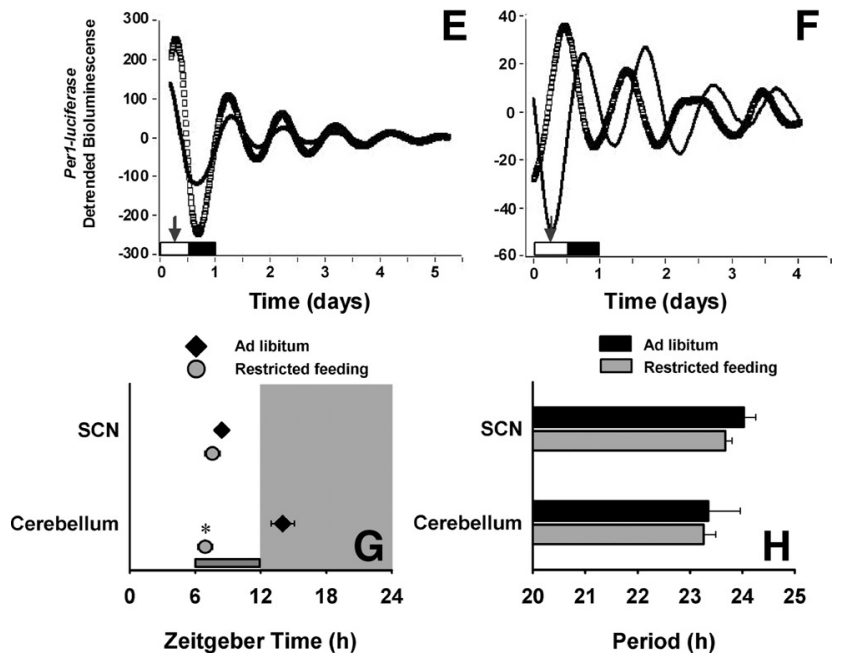

Figure 3. Rhythmic expression of Per1:luciferase in the cerebellum. $\boldsymbol{A}-\boldsymbol{F}$, Raw data are shown from the second day of recording in the suprachiasmatic region $(\mathrm{SCN})(\boldsymbol{A})$ and cerebellum (B) of ad libitum fed control animals and in the SCN $(\boldsymbol{C})$ and cerebellum (D) of animals that had been exposed to a $6 \mathrm{~h} \mathrm{RF}$ for $15 \mathrm{~d}$ at ZT6 (arrow). Detrended data of Per 1:Iuciferase in $\mathrm{SCN}(\boldsymbol{E})$ and cerebellum $(\boldsymbol{F})$ of ad libitum fed (filled circles) and RF animals (open squares). G, Phases of Per1:Iuciferase expression in the $\mathrm{SCN}$ and cerebellum of mice under conditions of food ad libitum and restricted feeding (mean \pm SEM of the first peak after a complete $24 \mathrm{~h}$ cycle in culture for each condition, $n=8$ and $n=5$ for $\mathrm{SCN}$ and cerebellum, respectively; ${ }^{*} p<0.05$ between feeding conditions for a given structure). $\boldsymbol{H}$, Endogenous periods of Per1:Iuciferase expression in the $\mathrm{SCN}$ and cerebellum of mice as in $\mathbf{G}$ (ZT12 = lights off).

of Per1:luciferase bioluminescence was not significantly different according to brain regions and feeding conditions (Fig. $3 H$ ). This second set of data demonstrates that the cerebellum contains a circadian oscillator able to sustain several oscillations when isolated in vitro and reset by timed feeding cues.

\section{Intraventricular injections of OX7-saporin}

Next, we investigated behavioral anticipation of mealtime in mice with a global impairment in cerebellar cortical function during adulthood. For that purpose, adult mice were injected in the lateral ventricle with OX7-saporin. Consistent with previous findings in rats (Mattsson et al., 2004; Nolan and Freeman, 2006), this immunotoxin in mice depleted Purkinje cells in a dosedependent manner, as assessed with calbindin D-28K immunostaining ( $p<0.05$; Fig. $4 A$ ). According to previous results in rats treated with intracerebroventricular OX7-saporin, visual inspection of mouse brain sections stained with cresyl violet suggests that deep cerebellar nuclei were spared by the immunotoxic le- sion (data not shown). Inferior olive in rats can be more or less damaged by intracerebroventricular OX7-saporin and cerebellar cortical lesions (Nolan and Freeman, 2006). In our mice treated with OX7-saporin, it cannot be fully excluded that cellular loss occurred in the inferior olive. Purkinje cell loss did not impair the daily amount and pattern of wheel-running activity in mice fed ad libitum ( $p=0.6$; Fig. $4 B$ ). When challenged with restricted feeding under light-dark cycle, mice that were given OX7-saporin showed nocturnal activity close or slightly increased compared with vehicle controls, again excluding ataxia as a side-effect in the results. In sharp contrast, food-anticipatory activity was significantly attenuated by OX7-saporin in all treated groups, albeit without dose-dependent differences, compared with the control group ( $p<0.05$; Fig. $4 B, C$ ). Furthermore, during a fasting test following the 2 week period of restricted feeding, all mice expressed a bout of locomotor activity before the expected mealtime, albeit at lower levels for OX7-saporin-treated mice compared with vehicle controls. This third set of data therefore highlights the involvement of Purkinje cells in the neural mechanisms of food entrainment.

\section{Cerebellar mutant (hotfoot) mice}

Finally, we studied food-anticipatory variables in mutant mice with impaired cerebellar circuitry that leads only to mild ataxic phenotype, thus avoiding putative confounding effects on foodanticipatory behavior. The Nancy hotfoot (ho) mutation causes deletion of the coding sequence of the ionotropic glutamate receptor $\delta 2$ gene (Grid2) which is selectively expressed in Purkinje cells (Kashiwabuchi et al., 1995; Lalouette et al., 1998). Grid2, identified by molecular cloning, does not bind to glutamate or to any known ligand (Lalouette et al., 1998). Interestingly, the ho mutation results in dendritic abnormalities of Purkinje cells that are detectable with electron microscopy (Guastavino et al., 1990; Kashiwabuchi et al., 1995) while global anatomical organization remains apparently normal in Grid $2^{\text {ho/ho }}$ mice (Fig. $2 D-F$ ). Impaired intracerebellar circuitry is thought to be responsible for the mild deficiency in motor coordination of Grid $2^{\text {ho/ho }}$ mice, similar to that observed in knock-out Grid2 mice (Kashiwabuchi et al., 1995) while the motor phenotype of Grid $2^{\text {ho/+ }}$ individuals appears essentially unaffected (Lalonde et al., 2003). The daily patterns of wheel-running activity, locomotor activity and body temperature in Grid $2^{\text {ho/ho }}$ mice fed ad libitum were very close to those of wild-type mice, with the exception of a small peak present at dawn in wild-type individuals and absent in mutants (Fig. 5A,B).

Concerning body temperature during restricted feeding under light-dark cycle, its values in wild-type mice before food access started from a lower level $(-3 \mathrm{~h})$ but reached significantly larger levels $(-1 \mathrm{~h})$ than those in Grid2 ${ }^{\text {ho/t }}$ and Grid2 ${ }^{\text {ho/ho }}$ mice that did not differ much in that respect (Fig. $5 A, B$ ). During and after feeding time, values of core temperature were essentially similar in the three genotypes, indicating comparable thermoregulatory processes (Fig. $5 A, B$ ). Furthermore, a robust foodanticipation activity was expressed before afternoon food access in wild-type mice. Interestingly, these anticipatory components were reduced in Grid2 $2^{\text {ho/t }}$ mice and almost abolished in Grid $2^{\text {ho/ho }}$ mice challenged with restricted feeding under lightdark cycle $(p<0.05$; Fig. $5 A, B)$. Conversely, levels of locomotor activity in Grid2 $2^{h o /+}$ and Grid2 ${ }^{\text {ho/ho }}$ mice were higher at early night than those in wild-type mice, indicating the reduction or lack of meal anticipation cannot be ascribed to ataxia. Thus, contrary to the mild ataxia observed in Grid2 $2^{\text {ho/ho }}$ mice, but not in Grid2 ${ }^{h o /+}$ individuals that are considered to be phenotypically 
A



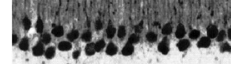

Veh

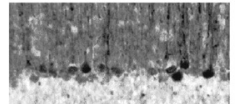

$0.25 \mu \mathrm{g}+\ldots$
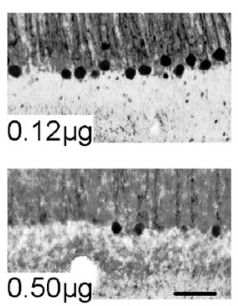

B

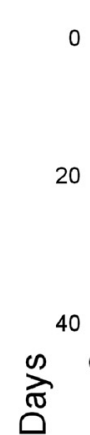

Veh

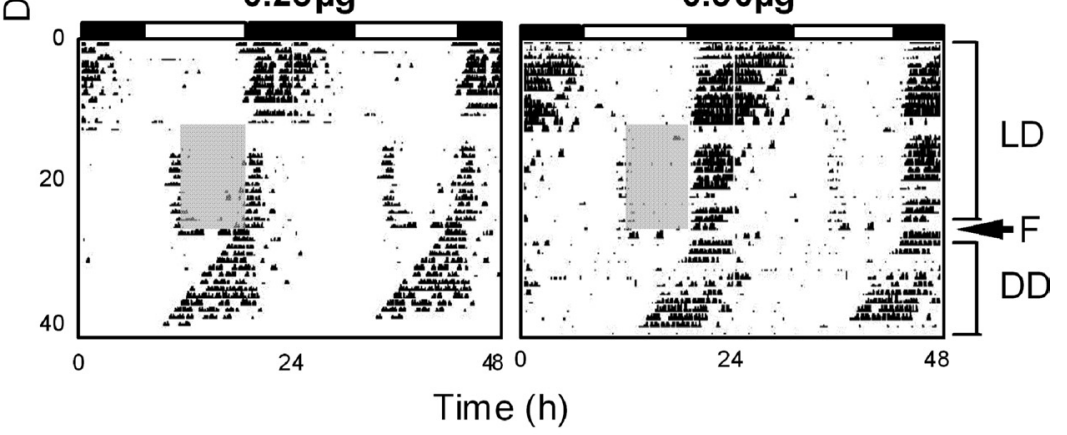

C
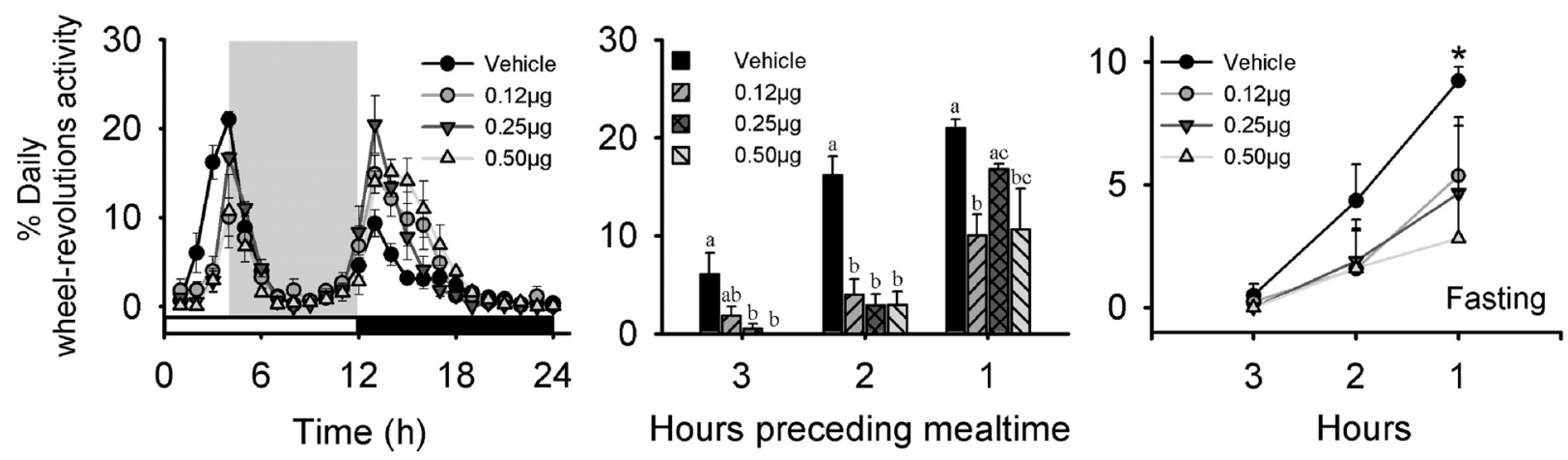

Figure 4. $\quad \boldsymbol{A}$, Number of Calbindin D-28K-immunoreactive (-ir) cells in the cerebellar cortex of mice treated with 0X-7 saporin. Values are expressed as the number of immunoreactive nuclei per section (6 per animal) in the cerebellar vermis of mice. Scale bar, $100 \mu \mathrm{m}$. $\boldsymbol{B}$, Wheel-running actograms of $0 X-7$ saporin and vehicle control mice under restricted feeding schedules (gray shaded bars). F, fasting day. C, Left, Profiles of wheel-running activity of $0 X-7$ saporin ( $n=4$ per dose) and vehicle control mice $(n=6)$ during food restriction (gray shaded area indicates period of food access). Middle, Group means of the activity percentage of mice from $3 \mathrm{~h}$ to $1 \mathrm{~h}$ before mealtime. Means lacking common letters are significantly different ( $p<0.05$ ). Right, Group means of the activity percentage of mice during the fasting from $3 \mathrm{~h}$ to $1 \mathrm{~h}$ before the expected mealtime. ${ }^{*}$ Treated groups are significantly different from the control group ( $p<0.05$ ).

identical to wild-type mice (Lalonde et al., 2003), there was a gene-dosage effect in the expression of behavioral anticipation of mealtime which was reduced and absent in Grid $2^{\text {ho/t }}$ and Grid $2^{\text {ho/ho }}$ mice, respectively. Of note, daily food intake and body mass during restricted feeding did not differ according to the genotype (supplemental Table S1, available at www.jneurosci.org as supplemental material, available at www.jneurosci.org as supplemental material). The initial phase of locomotor activity after transfer to constant darkness was phase-advanced by $1.3 \pm 0.3$, $0.8 \pm 0.3$, and $0.8 \pm 0.2 \mathrm{~h}$ in wild-type, Grid $2^{\text {ho/t }}$ and Grid2 ${ }^{\text {ho/ho }}$ mice, respectively $(p>0.05)$. Moreover, the free-running period did not differ between genotypes (Fig. 5A).

Next, to make sure the diminished anticipatory activity in Grid $2^{\text {ho/ho }}$ mice was not due to a masking effect of light that would inhibit locomotor activity during the light period, we exposed Grid $2^{\text {ho/ho }}$ mice and wild-type littermates to a restricted feeding in constant darkness. Wild-type mice expressed food-anticipatory bouts of general activity, wheel-running activity and body tem- perature during the $3 \mathrm{~h}$ preceding the daily food access. These food-anticipatory bouts were hardly detectable in Grid $2^{\text {ho/ho }}$ mice $(p<0.05$; Fig. $6 A, B)$. Note that in contrast to wild-type littermates, Grid $2^{\text {ho/ho }}$ mice showed increased general activity during the period of food access. Diet-induced thermogenesis resulting from food intake was similar in the two genotypes (Fig. 6A,B).

When food was available ad libitum, day-night variations of Per1, Per2, Rev-erb $\alpha$, and Dbp mRNA levels in the cerebellum were very close between wild-type and Grid $2^{\text {ho/ho }}$ mice, excepted that Per1 expression was upregulated in Grid $2^{\text {ho/ho }}$ individuals (Fig. 7A). Importantly, the increase of clock gene mRNA levels in the cerebellum of wild-type mice during meal anticipation under LD was absent in the cerebellum of Grid $2^{\text {ho/ho }}$ mice, suggesting that the circadian responses to mealtime at the molecular level are also altered in Grid2 $2^{\text {ho/ho }}$ mice (Fig. 7B).

Under ad libitum food conditions, day-night variations of Per1 expression in hypothalamic regions (i.e., the suprachiasmatic, dorsomedial nuclei and the arcuate nuclei) were present 
and in phase in both wild-type and Grid2 ${ }^{\text {ho/ho }}$ mice, with higher levels of Per1 mRNA in the arcuate nuclei of Grid $2^{\text {ho/ho }}$ individuals (Fig. 8). In sharp contrast to the findings in the cerebellum of the same animals, Perl expression in hypothalamic regions sensitive to mealtime, such as the arcuate and dorsomedial nuclei, was similarly increased before food access in both wild-type and Grid2 ${ }^{\text {ho/ho }}$ mice (Fig. 8). Furthermore, the day-night pattern of Per1 expression in the suprachiasmatic nuclei was affected by restricted feeding neither in wild-type, nor in Grid2 $2^{h o / h o}$ mice (Fig. 8). Overall changes of Per2 mRNA levels in the hypothalamic regions according to genotypes and feeding conditions were comparable to those described above for Perl expression (supplemental Fig. S3, available at www. jneurosci.org as supplemental material).

Finally, day-night variations in plasma corticosterone, glucose, free fatty acids and triacylglycerides did not differ significantly between wild-type and Grid $2^{\text {ho/ho }}$ mice fed ad libitum ( $p>0.1$; supplemental Fig. S4, available at www.jneurosci.org as supplemental material). Before mealtime, plasma corticosterone and metabolites did not differ between food-restricted Grid $2^{\text {ho/ho }}$ and wild-type mice, suggesting that the lack of food anticipation in cerebellar mutant mice is not due to impaired timing signals coming from the adrenal glands, the liver or the white adipose tissue $(p>0.1$; supplemental Fig. S4, available at www.jneurosci.org as supplemental material).

Thus, the marked phenotype (i.e., almost no food-anticipatory activity and temperature) in Grid2 ${ }^{\text {ho/ho }}$ mice with altered cerebellar circuitry strongly supports a presumed role of the cerebellum in food anticipation.

\section{Discussion}

The ability of the cerebellum to express near $24 \mathrm{~h}$ rhythms in vitro demonstrates that it contains a functional circadian oscillator, thus indicating the presence of a new component of the circadian timing system. Phase-shifting effects of restricted feeding on clock gene expression were found both ex vivo and in vitro, revealing that the cerebellar oscillator can be entrained to mealtime. Furthermore, the behavioral and physiological data strongly suggest that the cerebellar network plays a role in meal anticipation because mice with genetic cerebellar deficits ( Grid2 ${ }^{\text {ho/ho }}$ ) show no sizeable expression of behavioral, physiological and molecular food-anticipatory variables, while depletion of Purkinje cells in the cerebellar cortex with OX7-saporin markedly reduced behavioral anticipation of mealtime.
A
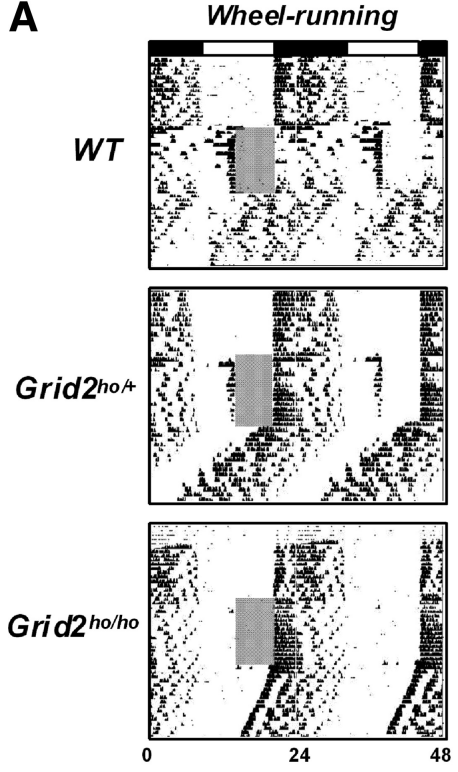

B
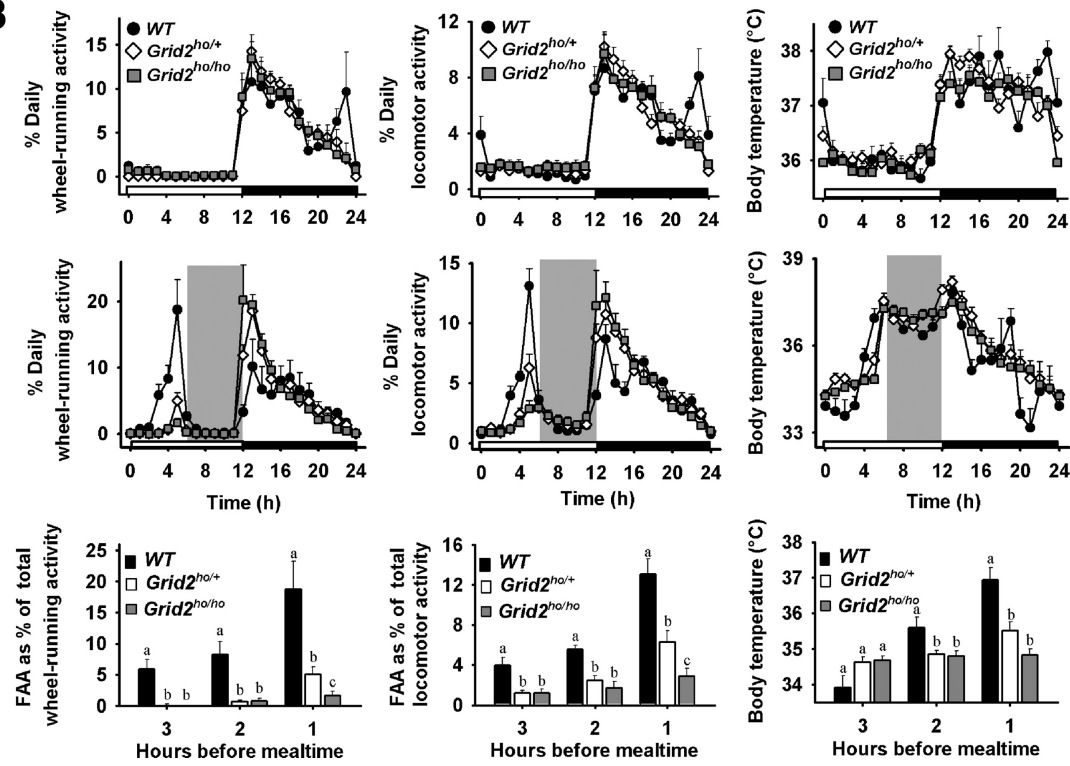

Body temperature
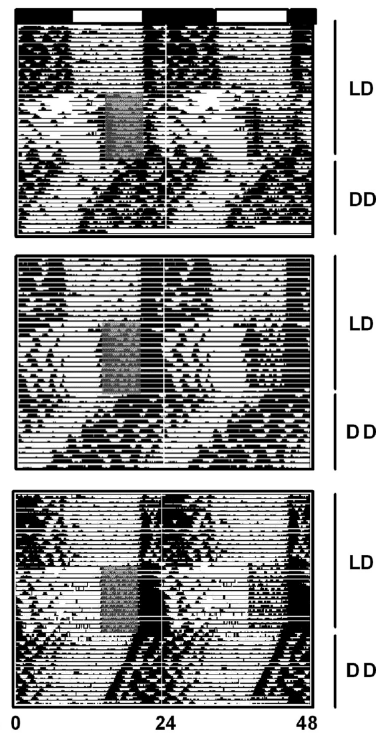

DD
Figure 5. Lack of food-anticipatory activity and temperature in cerebellar mutant $\left(G_{\text {rid }} 2^{\text {ho/ho }}\right)$ mice under a light-dark cycle. $A$, Wheel-running activity (left), general activity (middle) and body temperature (right) rhythms of wild-type, Grid2 ${ }^{\text {ho/+ }}$ and Grid $2^{\text {ho/ho }}$ mice. Each line represents $48 \mathrm{~h}$, plotted in 5 min bins. Gray shaded bars indicate time and number of days of food availability under LD conditions. After $20 \mathrm{~d}$ of food restriction, food was available ad libitum and animals were released in DD. $\boldsymbol{B}$, Top, Profiles of wheel-running activity (left), general activity (middle) and body temperature (right) rhythms in wild-type, Grid2 ${ }^{\text {ho/+ }}$ and Grid2 ${ }^{\text {ho/ho }}$ mice under baseline conditions with food ad libitum. Middle, Profiles of wheel-running activity (left), general activity (middle) and body temperature profiles (right) of mice under restricted feeding schedules (gray shaded area; food available during $6 \mathrm{~h}$ from midday to lights off). Bottom, Food-anticipatory components (percentage of daily values) of wheelrunning activity (left), general activity (middle), and body temperature (right) in food-restricted wild-type, Grid2 ${ }^{\text {ho/ }}$ and Grid2 ${ }^{\text {ho/ho }}$ mice from $3 \mathrm{~h}$ to $1 \mathrm{~h}$ before mealtime. Food was available during $6 \mathrm{~h}$ from midday to lights off. Means lacking common letters are significantly different $(p<0.05)$.

Clock gene expression in the cerebellum is shifted by daytime feeding

The daily rhythmic expression of Perl in the mouse cerebellum with a peak in early nighttime confirms previous descriptions in that structure (Akiyama et al., 1999; Farnell et al., 2008). Furthermore, these ex vivo gene expression data match the rhythmic pattern of Per1-luciferase bioluminescence in the rat cerebellum that peaks at projected ZT14 when measured in vitro. Our analysis of clock gene expression in the mouse cere- 


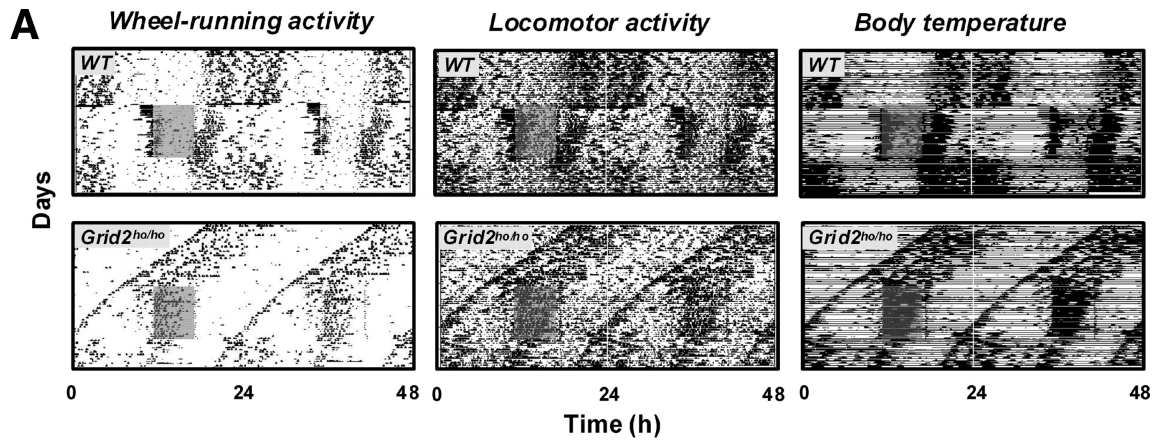

B
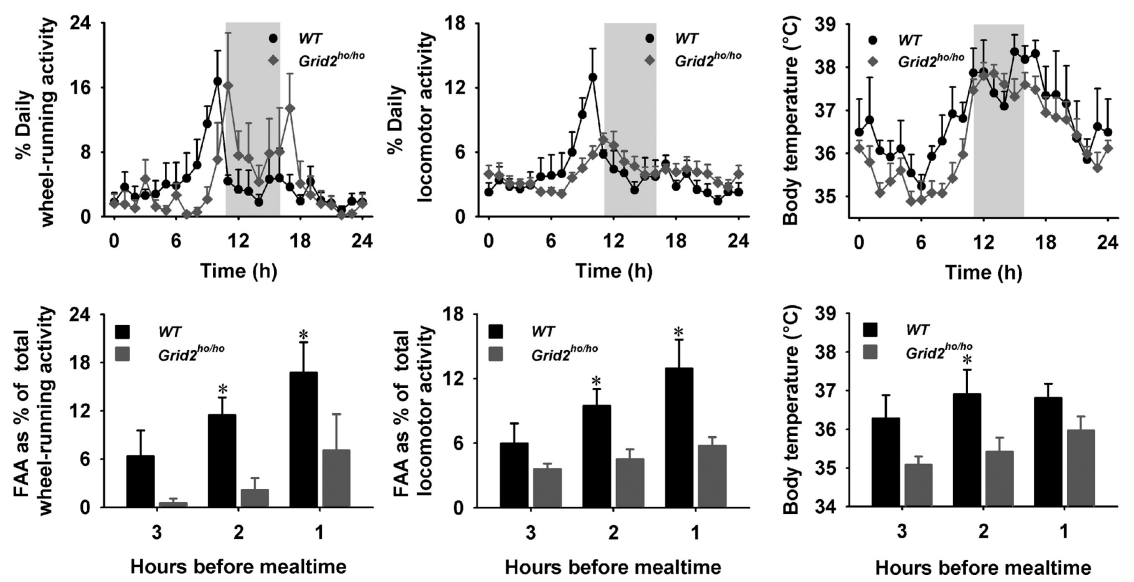

Figure 6. Lack of food-anticipatory activity and body temperature in cerebellar mutant (Grid2 ${ }^{\text {ho/ho }}$ ) mice under constant darkness. $\boldsymbol{A}$, Wheel-running (left), general activity (middle), and body temperature (right) rhythms of wild-type and Grid $2^{\text {ho/ho }}$ mice exposed to restricted feeding in DD conditions. Gray shaded bars indicate time and number of days of food availability. $\boldsymbol{B}$, Top, Profiles of wheel-running activity, general activity, and body temperature in wild-type $(n=8)$ and Grid2 ${ }^{\text {ho/ho }}$ mice $(n=7)$ averaged in $1 \mathrm{~h}$ bins over the $24 \mathrm{~h}$ cycle. Gray shaded area indicates daily $6 \mathrm{~h}$ access to food. Bottom, Food-anticipatory components (percentage of daily values) of wheel-running activity (left), general activity (middle) and body temperature (right) in foodrestricted wild-type and Grid $2^{\text {ho/ho }}$ mice from $3 \mathrm{~h}$ to $1 \mathrm{~h}$ before mealtime. ${ }^{*} p<0.05$ between genotypes for a given time point.

bellum reveals phase-relationships of cycling expression of Per1, Per2, Rev-erb $\alpha$, and Dbp consistent to those known in the molecular clockwork (e.g., in the liver; see Feillet et al., 2006). Daynight expression of Bmall in the cerebellum of mice fed ad libitum is high and low at midday and midnight, respectively (C. Graff and E. Challet, unpublished data), as already observed (Namihira et al., 1999) and in accordance with its role as a transcriptional activator of Rev-erb $\alpha$ and Per genes. The daily expression of PER2 was delayed by $\sim 5 \mathrm{~h}$ compared with the cycling of Per2, in keeping with the $4-6 \mathrm{~h}$ lag found in the suprachiasmatic nuclei (Field et al., 2000; Mendoza et al., 2007). Moreover, immunohistochemical staining indicates that the cerebellar oscillator likely resides in the Purkinje cells.

Daytime restricted feeding or hypocaloric feeding under a light-dark cycle changes the phase of clock genes and proteins oscillations in the cerebellar cortex. The phase advance for Per oscillations was larger than that for Rev-erb $\alpha$ ( 8 h versus $3 \mathrm{~h}$, respectively). Furthermore, day-night variations of Bmal1 in the cerebellum were inverted by daytime feeding (Graff and Challet, unpublished data). Therefore, the cerebellar clockwork is clearly sensitive to, and phase-adjusted by, feeding cues. Comparable phase-resetting effects of timed feeding on circadian oscillations of clock genes/proteins have been previously observed in a number of, but not in all, forebrain regions outside the suprachiasmatic nuclei (Wakamatsu et al., 2001; Mieda et al., 2006; AngelesCastellanos et al., 2007; Verwey et al., 2007; Feillet et al., 2008).
Food anticipation is attenuated or lacking in mice with cerebellar damage To establish a role of the cerebellar oscillator in meal anticipation, Purkinje cells in the cerebellar cortex were damaged with OX7-saporin. This immunotoxic lesion that damages the cerebellar cortex and spares cerebellar deep nuclei (Nolan and Freeman, 2006) markedly reduced food-anticipatory activity.

The line of cerebellar mutants we tested were mice bearing the Nancy hotfoot (ho) mutation. The phenotype of Grid $2^{\text {ho/ho }}$ mice that have impaired cerebellar circuitry (Lalouette et al., 1998) was very strong, as these mice did not show food-anticipatory behaviors in a lightdark cycle nor in constant darkness. It is important to note that this lack of meal anticipation was associated with altered changes of clock gene expression in the cerebellum of food-restricted Grid2 $2^{\text {ho/ho }}$ mice, suggesting that a functional cerebellar oscillator may play a critical role in food-anticipatory processes. Furthermore, Per 1 and Per 2 expression in the hypothalamus of these cerebellar mutants was similarly phased as in wild-type mice challenged with restricted feeding in accordance with previous studies in the same hypothalamic regions (Mieda et al., 2006; Moryia et al., 2009). This finding suggests that the feeding-associated circadian system relies on a widely distributed network including the cerebellum and controlling food-anticipatory processes, and that several (hypothalamic) components can be shifted by feeding cues independently.

\section{The cerebellar oscillator belongs to the feeding-associated circadian network}

Even if the cerebellum is largely acknowledged as a motor coordinator, it also modulates motor and spatial learning and participates in temporal discrimination (see Introduction). A few works have also implicated the cerebellum in the regulation of feeding (Mahler et al., 1993; Zhu and Wang, 2008). Interestingly, regional cerebral blood flow, used as a marker of neuronal activation, is selectively increased in the cerebellum of hungry patients, suggesting that metabolic signals associated with hunger reach this brain region (Tataranni et al., 1999). Neuropeptide Y is a potent orexigenic neuropeptide that is expressed not only in the arcuate nucleus of the hypothalamus, but also in the nucleus of the solitary tract and the cerebellum (Ishizaki et al., 2003). In that study, the autoradiograms strongly suggest that the transcription of neuropeptide $Y$ gene in the cerebellar cortex is highly activated by both restricted feeding and food deprivation. The present data further indicate that the cerebellar cortex is involved in anticipation of mealtime, a process thought to combine circadian time measurement and resetting by feeding cues (Mistlberger, 1994).

The neural mechanisms of food anticipation are not well understood yet. Until now, the lesion strategy that has been successful to identify the light-entrainable clock within the suprachiasmatic nuclei failed to identify well circumscribed cerebral 

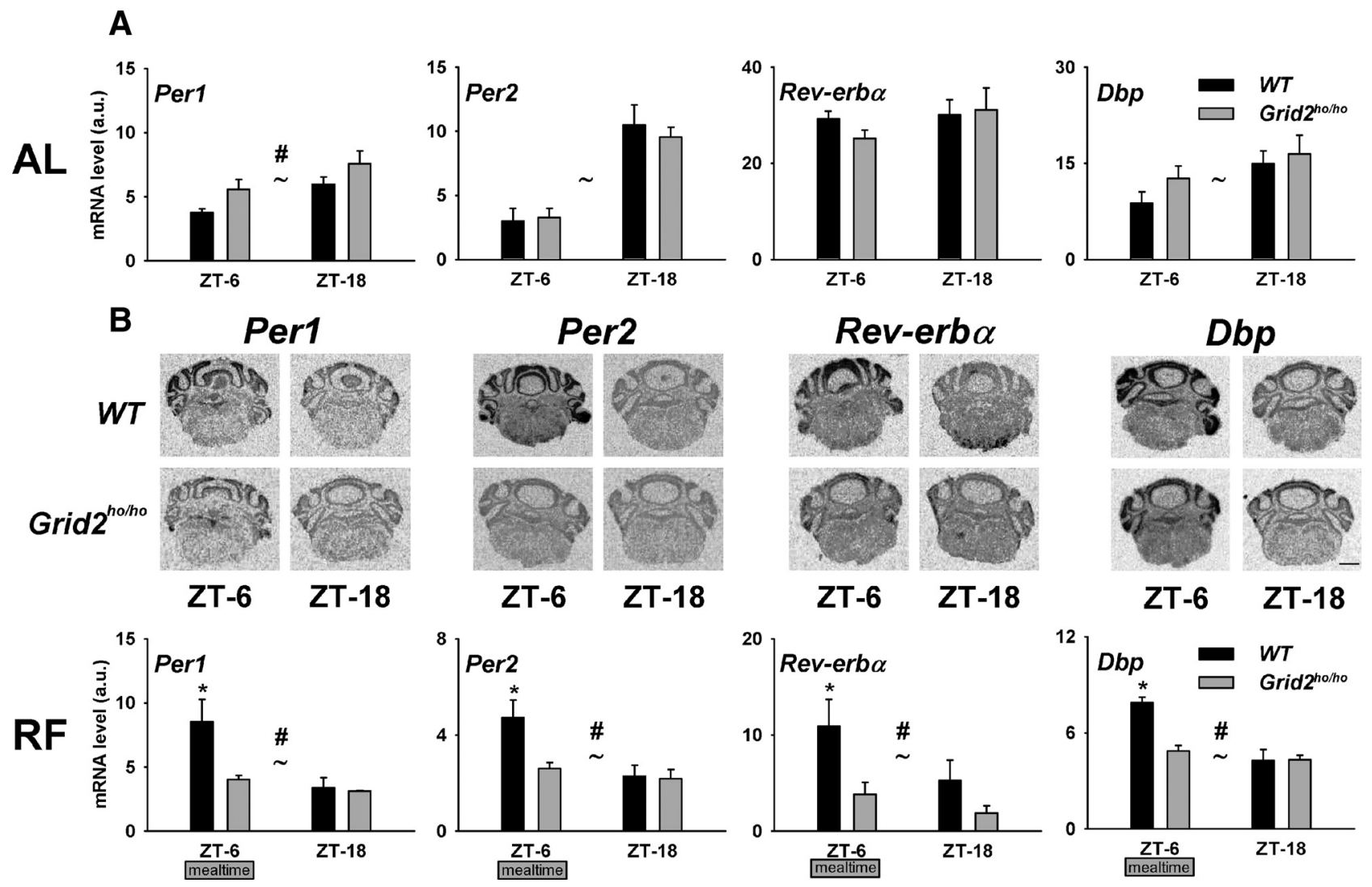

Figure 7. A, Day-night variations of clock gene expression in the cerebellum from wild-type ( $n=5$ per ZT) and Grid $2^{\text {ho/ho }}$ mice $(n=5$ per ZT) fed ad libitum. $\sim p<0.05$ between time points; ${ }^{\#} p<0.05$ between genotypes. $\boldsymbol{B}$, Top, Expression of Per1, Per2, Rev-erb $\alpha$, and Dbp in the cerebellum of wild-type and Grid2 ${ }^{\text {ho/ho }}$ mice exposed to restricted feeding. Scale bar, $100 \mu \mathrm{m}$. Bottom, Day-night variations of clock gene expression in the cerebellum from wild-type $(n=8)$ and Grid2 ${ }^{\text {ho/ho }}$ mice $(n=7)$ exposed to restricted feeding (food available during $6 \mathrm{~h}$ from midday to lights off). Animals were killed at ZT6 (i.e., just before mealtime) and $12 \mathrm{~h}$ later (ZT18). $\sim p<0.05$ between time points; ${ }^{*} p<0.05$ genotype $\times$ time interaction; ${ }^{*} p<0.05$ between genotypes for a given time point (ZT12 = lights off).

regions specifically involved in meal anticipation, that is, brain regions whose destruction fully eliminates food-anticipatory processes. As mentioned in the Introduction, however, food-anticipatory components can be reduced after lesions of the parabrachial nucleus (Davidson et al., 2000), the core of the accumbens nucleus (Mendoza et al., 2005b) and possibly the dorsomedial hypothalamus (Gooley et al., 2006). The role of this hypothalamic region in food anticipation, however, remains highly controversial (Landry et al., 2006; Mistlberger et al., 2009; Moriya et al., 2009). This relative paucity of positive findings despite extensive research has led to the hypothesis that the food-entrainable oscillator may actually not be localized in a particular brain region but instead, may involve a distributed cerebral network resulting from interactions of a set of brain regions directly sensitive or not to metabolic cues coming from peripheral organs (Mistlberger, 1994; Stephan, 2001; Mendoza, 2007). In accordance with previous observations of functional changes in the cerebellum during food anticipation (de Vasconcelos et al., 2006), the present data clearly indicate for the first time that the cerebellar oscillator can integrate temporal cues associated with feeding time. In that respect, the cerebellum
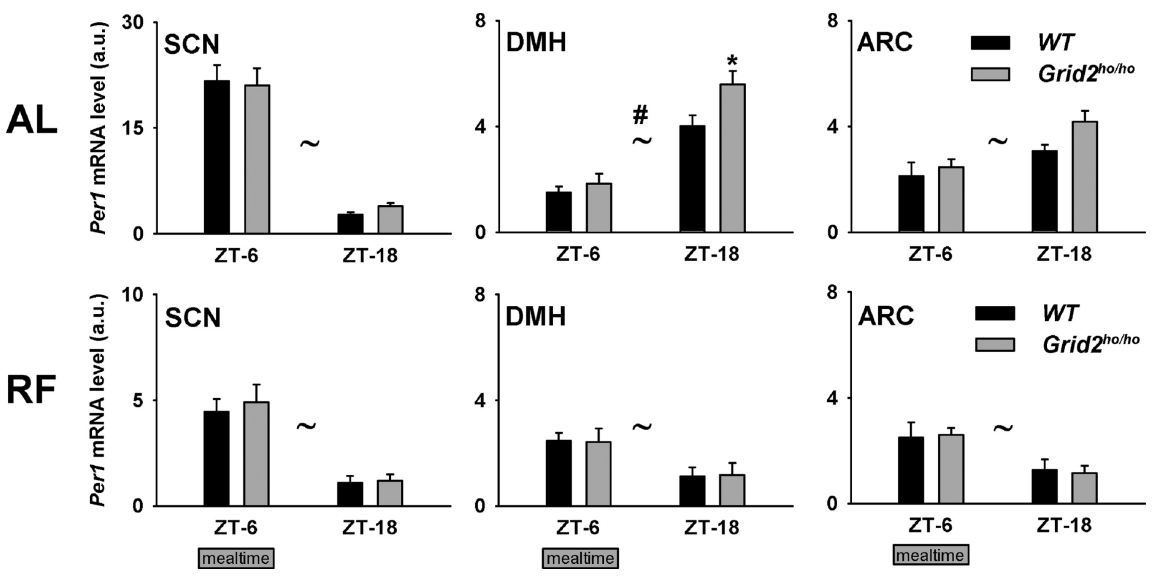

Figure 8. Day-night variations of expression of Per1 clock gene in the suprachiasmatic (SCN), dorsomedial hypothalamic (DMH), and arcuate nuclei (ARC) from wild-type and Grid $2^{\text {ho/ho }}$ mice either fed ad libitum (AL; top) or exposed to restricted feeding [(RF) food available during $6 \mathrm{~h}$ from midday to lights off, bottom]. Animals were killed at ZT6 (i.e., just before mealtime in food-restricted mice) and $12 \mathrm{~h}$ later (ZT18). $\sim p<0.05$ between time points; ${ }^{*} p<0.05$ between genotypes; ${ }^{*} p<0.05$ between genotypes for a given time point (ZT12 = lights off).

is either one of the links within the feeding-associated circadian network or a critical region for mealtime processing.

Afferent pathways conveying nutritional cues to the cerebellar oscillator

One possibility for the cerebellar clockwork to be reset by feeding cues is that blood-borne signals penetrate into the CNS via cir- 
cumventricular organs devoid of the blood-brain barrier before reaching cerebellar targets. For instance, the cerebellum expresses a high density of leptin receptors (Guan et al., 1997) whose expression is clearly downregulated by high-fat feeding (Koros et al., 2009), suggesting that peripheral leptin could well transmit metabolic signals to that structure. Another example is the expression of glucose transporters (Glut), including the insulinresponsive Glut4, in the cerebellum (El Messari et al., 1998; Choeiri et al., 2002), suggesting that glucose and/or insulin could provide afferent signals to that brain region.

Alternatively, the cerebellum can receive indirect feeding cues via identified neural routes after integration of blood-borne signals by the brainstem (nucleus of the solitary tract/parabrachial nucleus) or mediobasal hypothalamus (arcuate nucleus, ventromedial hypothamic nucleus; see Zhu and Wang, 2008). Because changes of Per1 expression in the arcuate and dorsomedial hypothalamic nuclei were similar in food-restricted wild-type mice and Grid2 $2^{h / h o}$ mice, respectively, expressing or not food-anticipatory activity, this finding suggests that the mediobasal hypothalamus is not critical for cerebellar synchronization to feeding. In addition another route exists, identified by extracellular recording in the deep cerebellar nuclei after gastric vagal stimulation, which conveys peripheral signals to the cerebellar network via the vagus nerve (Li et al., 2009). These data indicate that the cerebellum can either directly sense metabolic signals or receive them indirectly via multiple neural projections.

The parabrachial nucleus and locus ceruleus may play a role in conveying nutritional cues to the feeding-associated circadian network (Davidson et al., 2000; Warnecke et al., 2005). Connections to the cerebellum coming from the parabrachial nucleus and locus ceruleus have already been characterized (Dietrichs, 1985). Furthermore, the hodological studies described above make possible that neuronal projections could also transmit feeding cues from sensitive areas in the ventromedial hypothalamus to the cerebellum. As evoked earlier, the cerebellum could directly detect some blood-borne nutritional signals. Once processed by the cerebellar cortex, temporal messages associated with feeding/metabolic cues would then be transferred via identified neural pathways (Cavdar et al., 2001; Zhu et al., 2006) to relay structures controlling the outputs, including hypothalamic, thalamic and cortical areas for the control of food-anticipatory activity and temperature.

Future research will be necessary to identify the nature of nutritional cues (i.e., hormones or metabolites) and the mechanisms by which they might reset the cerebellar clockwork.

\section{References}

Abe M, Herzog ED, Yamazaki S, Straume M, Tei H, Sakaki Y, Menaker M, Block GD (2002) Circadian rhythms in isolated brain regions. J Neurosci 22:350-356.

Akiyama M, Kirihara T, Takahashi S, Minami Y, Yoshinobu Y, Moriya T, Shibata S (1999) Modulation of mPerl gene expression by anxiolytic drugs in mouse cerebellum. Br J Pharmacol 128:1616-1622.

Angeles-Castellanos M, Mendoza J, Escobar C (2007) Restricted feeding schedules phase shift daily rhythms of c-Fos and protein Per1 immunoreactivity in corticolimbic regions in rats. Neuroscience 144:344-355.

Blum ID, Patterson Z, Khazall R, Lamont EW, Sleeman MW, Horvath TL, Abizaid A (2009) Reduced anticipatory locomotor responses to scheduled meals in ghrelin receptor deficient mice. Neuroscience 164:351-359.

Caston J, Chianale C, Delhaye-Bouchaud N, Mariani J (1998) Role of the cerebellum in exploration behavior. Brain Res 808:232-237.

Cavdar S, San T, Aker R, Sehirli U, Onat F (2001) Cerebellar connections to the dorsomedial and posterior nuclei of the hypothalamus in the rat. J Anat 198:37-45

Choeiri C, Staines W, Messier C (2002) Immunohistochemical localization and quantification of glucose transporters in the mouse brain. Neuroscience 111:19-34.

D’Agata V, Drago F, Serapide F, Cicirata F (1993) Effects of cerebellectomy on motivation-related behavior: a time-course study. Physiol Behav 53:173-176.

Damiola F, Le Minh N, Preitner N, Kornmann B, Fleury-Olela F, Schibler U (2000) Restricted feeding uncouples circadian oscillators in peripheral tissues from the central pacemaker in the suprachiasmatic nucleus. Genes Dev 14:2950-2961.

Davidson AJ, Cappendijk SL, Stephan FK (2000) Feeding-entrained circadian rhythms are attenuated by lesions of the parabrachial region in rats. Am J Physiol Regul Integr Comp Physiol 278:R1296-R1304.

Davidson AJ, Poole AS, Yamazaki S, Menaker M (2003) Is the foodentrainable circadian oscillator in the digestive system? Genes Brain Behav 2:32-39.

de Vasconcelos AP, Bartol-Munier I, Feillet CA, Gourmelen S, Pévet P, Challet $\mathrm{E}$ (2006) Modifications of local cerebral glucose utilization during circadian food-anticipatory activity. Neuroscience 139:741-748.

Dietrichs E (1985) Divergent axon collaterals to cerebellum and amygdala from neurons in the parabrachial nucleus, the nucleus locus coeruleus and some adjacent nuclei. A fluorescent double labelling study using rhodamine labelled latex microspheres and fast blue as retrograde tracers. Anat Embryol (Berl) 172:375-382.

Ebner TJ (1998) A role for the cerebellum in the control of limb movement velocity. Curr Opin Neurobiol 8:762-769.

El Messari S, Leloup C, Quignon M, Brisorgueil MJ, Penicaud L, Arluison M (1998) Immunocytochemical localization of the insulin-responsive glucose transporter 4 (Glut4) in the rat central nervous system. J Comp Neurol 399:492-512.

Farnell YZ, Allen GC, Nahm SS, Neuendorff N, West JR, Chen WJ, Earnest DJ (2008) Neonatal alcohol exposure differentially alters clock gene oscillations within the suprachiasmatic nucleus, cerebellum, and liver of adult rats. Alcohol Clin Exp Res 32:544-552.

Feillet CA, Ripperger JA, Magnone MC, Dulloo A, Albrecht U, Challet E (2006) Lack of food anticipation in Per2 mutant mice. Curr Biol 16:2016-2022.

Feillet CA, Mendoza J, Albrecht U, Pévet P, Challet E (2008) Forebrain oscillators ticking with different clock hands. Mol Cell Neurosci 37:209-221.

Field MD, Maywood ES, O’Brien JA, Weaver DR, Reppert SM, Hastings MH (2000) Analysis of clock proteins in mouse SCN demonstrates phylogenetic divergence of the circadian clockwork and resetting mechanisms. Neuron 25:437-447.

Gooley JJ, Schomer A, Saper CB (2006) The dorsomedial hypothalamic nucleus is critical for the expression of food-entrainable circadian rhythms. Nat Neurosci 9:398-407.

Guan XM, Hess JF, Yu H, Hey PJ, van der Ploeg LH (1997) Differential expression of mRNA for leptin receptor isoforms in the rat brain. Mol Cell Endocrinol 133:1-7.

Guastavino JM, Sotelo C, Damez-Kinselle I (1990) Hot-foot murine mutation: behavioral effects and neuroanatomical alterations. Brain Res 523:199-210

Hara R, Wan K, Wakamatsu H, Aida R, Moriya T, Akiyama M, Shibata S (2001) Restricted feeding entrains liver clock without participation of the suprachiasmatic nucleus. Genes Cells 6:269-278.

Hastings M, O’Neill JS, Maywood ES (2007) Circadian clocks: regulators of endocrine and metabolic rhythms. J Endocrinol 195:187-198.

Ishizaki K, Honma S, Katsuno Y, Abe H, Masubuchi S, Namihira M, Honma $\mathrm{K}$ (2003) Gene expression of neuropeptide $\mathrm{Y}$ in the nucleus of the solitary tract is activated in rats under restricted daily feeding but not under 48-h food deprivation. Eur J Neurosci 17:2097-2105.

Ivry RB, Spencer RM, Zelaznik HN, Diedrichsen J (2002) The cerebellum and event timing. Ann N Y Acad Sci 978:302-317.

Kashiwabuchi N, Ikeda K, Araki K, Hirano T, Shibuki K, Takayama C, Inoue Y, Kutsuwada T, Yagi T, Kang Y, Aizawa S, Mishina M (1995) Impairment of motor coordination, Purkinje cell synapse formation, and cerebellar long-term depression in GluR delta 2 mutant mice. Cell 81:245-252.

Koros C, Boukouvalas G, Gerozissis K, Kitraki E (2009) Fat diet affects leptin receptor levels in the rat cerebellum. Nutrition 25:85-87.

Lalonde R, Botez MI (1990) The cerebellum and learning processes in animals. Brain Res Brain Res Rev 15:325-332. 
Lalonde R, Hayzoun K, Selimi F, Mariani J, Strazielle C (2003) Motor coordination in mice with hotfoot, Lurcher, and double mutations of the Grid2 gene encoding the delta-2 excitatory amino acid receptor. Physiol Behav 80:333-339.

Lalouette A, Guénet JL, Vriz S (1998) Hotfoot mouse mutations affect the delta 2 glutamate receptor gene and are allelic to lurcher. Genomics 50:9-13.

Landry GJ, Simon MM, Webb IC, Mistlberger RE (2006) Persistence of a behavioral food-anticipatory circadian rhythm following dorsomedial hypothalamic ablation in rats. Am J Physiol Regul Integr Comp Physiol 290:R1527-R1534.

LeSauter J, Hoque N, Weintraub M, Pfaff DW, Silver R (2009) Stomach ghrelin-secreting cells as food-entrainable circadian clocks. Proc Natl Acad Sci U S A 106:13582-13587.

Li B, Guo CL, Tang J, Zhu JN, Wang JJ (2009) Cerebellar fastigial nuclear inputs and peripheral feeding signals converge on neurons in the dorsomedial hypothalamic nucleus. Neurosignals 17:132-143.

Mahler P, Guastavino JM, Jacquart G, Strazielle C (1993) An unexpected role of the cerebellum: involvement in nutritional organization. Physiol Behav 54:1063-1067.

Marchant EG, Mistlberger RE (1997) Anticipation and entrainment to feeding time in intact and SCN-ablated C57BL/6j mice. Brain Res 765:273-282.

Mattsson A, Pernold K, Ogren SO, Olson L (2004) Loss of cortical acetylcholine enhances amphetamine-induced locomotor activity. Neuroscience 127:579-591.

Mauk MD, Buonomano DV (2004) The neural basis of temporal processing. Annu Rev Neurosci 27:307-340.

Meijer JH, Schwartz WJ (2003) In search of the pathways for light-induced pacemaker resetting in the suprachiasmatic nucleus. J Biol Rhythms 18:235-249.

Mendoza J (2007) Circadian clocks: setting time by food. J Neuroendocrinol 19:127-137.

Mendoza J, Graff C, Dardente H, Pévet P, Challet E (2005a) Feeding cues alter clock gene oscillations and photic responses in the suprachiasmatic nuclei of mice exposed to a light-dark cycle. J Neurosci 25:1514-1522.

Mendoza J, Angeles-Castellanos M, Escobar C (2005b) Differential role of the accumbens Shell and Core subterritories in food-entrained rhythms of rats. Behav Brain Res 158:133-142.

Mendoza J, Pévet P, Challet E (2007) Circadian and photic regulation of clock and clock-controlled proteins in the suprachiasmatic nuclei of calorie-restricted mice. Eur J Neurosci 25:3691-3701.

Mieda M, Williams SC, Richardson JA, Tanaka K, Yanagisawa M (2006) The dorsomedial hypothalamic nucleus as a putative food-entrainable circadian pacemaker. Proc Natl Acad Sci U S A 103:12150-12155.

Mistlberger RE (1994) Circadian food-anticipatory activity: Formal models and physiological mechanisms. Neurosci Biobehav Rev 18:171-195.

Mistlberger RE, Marchant EG (1999) Enhanced food-anticipatory circadian rhythms in the genetically obese Zucker rat. Physiol Behav 66:329-335.

Mistlberger RE, Buijs RM, Challet E, Escobar C, Landry GJ, Kalsbeek A, Pévet P, Shibata S (2009) Standards of evidence in chronobiology: critical review of a report that restoration of Bmall expression in the dorsomedial hypothalamus is sufficient to restore circadian food anticipatory rhythms in Bmal1-/- mice. J Circadian Rhythms 7:3.

Moriya T, Aida R, Kudo T, Akiyama M, Doi M, Hayasaka N, Nakahata N,
Mistlberger R, Okamura H, Shibata S (2009) The dorsomedial hypothalamic nucleus is not necessary for food-anticipatory circadian rhythms of behavior, temperature or clock gene expression in mice. Eur J Neurosci 29:1447-1460.

Namihira M, Honma S, Abe H, Tanahashi Y, Ikeda M, Honma K (1999) Daily variation and light responsiveness of mammalian clock gene, Clock and BMAL1, transcripts in the pineal body and different areas of brain in rats. Neurosci Lett 267:69-72.

Nolan BC, Freeman JH (2006) Purkinje cell loss by OX7-saporin impairs acquisition and extinction of eyeblink conditioning. Learn Mem 13:359-365.

Poulin AM, Timofeeva E (2008) The dynamics of neuronal activation during food anticipation and feeding in the brain of food-entrained rats Brain Res 1227:128-141.

Ralph MR, Foster RG, Davis FC, Menaker M (1990) Transplanted suprachiasmatic nucleus determines circadian period. Science 247:975-978.

Shadmehr R, Krakauer JW (2008) A computational neuroanatomy for motor control. Exp Brain Res 185:359-381.

Stephan FK (2001) Food-entrainable oscillators in mammals. In: Handbook of behavioral neurobiology, Vol 12, Circadian clocks (Takahashi JS, Turek FW, Moore RY, eds), pp 223-246. New York: Kluwer Academic/Plenum.

Stephan FK, Swann JM, Sisk CL (1979) Entrainment of circadian rhythms by feeding schedules in rats with suprachiasmatic lesions. Behav Neural Biol 25:545-554.

Stokkan KA, Yamazaki S, Tei H, Sakaki Y, Menaker M (2001) Entrainment of the circadian clock in the liver by feeding. Science 291:490-493.

Tataranni PA, Gautier JF, Chen K, Uecker A, Bandy D, Salbe AD, Pratley RE, Lawson M, Reiman EM, Ravussin E (1999) Neuroanatomical correlates of hunger and satiation in humans using positron emission tomography. Proc Natl Acad Sci U S A 96:4569-4574.

Verwey M, Khoja Z, Stewart J, Amir S (2007) Differential regulation of the expression of Period2 protein in the limbic forebrain and dorsomedial hypothalamus by daily limited access to highly palatable food in fooddeprived and free-fed rats. Neuroscience 147:277-285.

Wakamatsu H, Yoshinobu Y, Aida R, Moriya T, Akiyama M, Shibata S (2001) Restricted-feeding-induced anticipatory activity rhythm is associated with a phase-shift of the expression of mPer1 and mPer2 mRNA in the cerebral cortex and hippocampus but not in the suprachiasmatic nucleus of mice. Eur J Neurosci 13:1190-1196.

Warnecke M, Oster H, Revelli JP, Alvarez-Bolado G, Eichele G (2005) Abnormal development of the locus coeruleus in Ear2(Nr2f6)-deficient mice impairs the functionality of the forebrain clock and affects nociception. Genes Dev 19:614-625.

Yamazaki S, Takahashi JS (2005) Real-time luminescence reporting of circadian gene expression in mammals. Methods Enzymol 393:288-301.

Yamazaki S, Numano R, Abe M, Hida A, Takahashi R, Ueda M, Block GD, Sakaki Y, Menaker M, Tei H (2000) Resetting central and periphera circadian oscillators in transgenic rats. Science 288:682-685.

Zhu JN, Wang JJ (2008) The cerebellum in feeding control: possible function and mechanism. Cell Mol Neurobiol 28:469-478.

Zhu JN, Li HZ, Ding Y, Wang JJ (2006) Cerebellar modulation of feedingrelated neurons in rat dorsomedial hypothalamic nucleus. J Neurosci Res 84:1597-1609. 